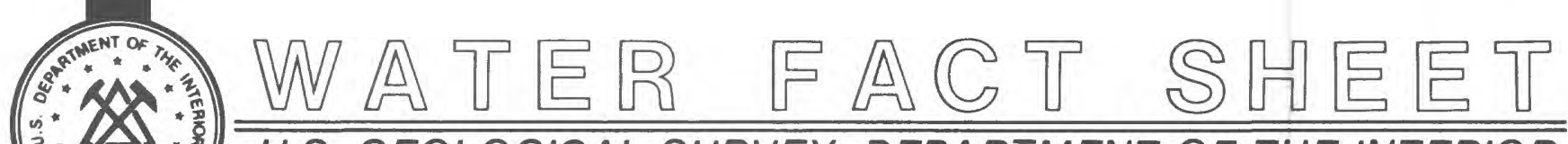

U.S. GEOLOGICAL SURVEY, DEPARTMENT OF THE INTERIOR

\title{
HISTORY OF WATER RESOURCES ACTIVITIES OF THE U.S. GEOLOGICAL SURVEY
}

\section{THE EARLY YEARS: 1879-1925}

The U.S. Geological Survey, the Nation's largest earth-science agency, was established in 1879 following several Federally sponsored independent natural resource surveys of the West and Midwest. National interest in developing arid and semiarid lands resulted in the establishment of the Irrigation Survey, the forerunner of the Water Resources Division, in 1888 to study the availability of water for irrigation, sites for reservoirs, and artesian areas of the arid and semiarid lands of the United States. The pioneering foreign assignment probably was that of H.M. Wilson who was sent to India in the winter of 1889 to observe irrigation methods for application to developing practices in the Western United States. The Irrigation Survey was terminated in 1890 , but streamflow measurements continued in a modest way until 1894, when Congress authorized the Geological Survey to gage streams and determine the water supply of the United States, including the investigation of ground water. Highlights and milestones of the Geological Survey's almost 100 years of water resources activities follow:

- First cooperative water resources study began with the State of Kansas in 1895.

- The first Water-Supply Paper was published in 1896 and the second in 1897.

- The Division of Hydrography was established in 1897 to continue measurement of streamflow and study of ground water.

- The Geological Survey began its studies of ground water for irrigation purposes in southern California in 1900.

- Reservoir surveys and gaging, diversion surveys and gaging, artesian surveys and gaging, waterpower surveys and gag ing, and sanitary surveys (the first real emphasis on quality of natural waters) began in 1901.

- The Survey and the Department of Agriculture were cooperating in 1901 to preserve forests in watersheds and to develop waterpower.

- Scope of studies was extended to the entire United States by legislation passed in 1902, and the Hydrographic Branch replaced the Hydrographic Division.

- The Reclamation Service (now the U.S. Bureau of Reclamation) was established in 1902 under the administration of Survey officers.

- The Hydrology Division (now the Office of Ground Water in the Hydrographic Branch was organized in 1903 for the collection of well and spring data.

- Flood studies became part of the Survey's water-resources program in 1903 following disastrous floods in the Passaic River basin in northern New Jersey in 1902 and 1903.

- The Division of Hydro-economics (now the Office of Water Quality) was established in 1903 to study the economic value in the Nation's water supplies.

- By 1904, the maximum, minimum, and mean discharges of all the more important rivers had been recorded for 15 years.

- The first work primarily for the purpose of studying groundwater conditions began in Utah in 1904.

- Information on physical characteristics of river basins, irrigable lands and canal lines, and reservoir sites and irrigation projects had been published in about 150 reports by 1905.
- The Hydrologic Branch became the "Water Resources Branch" in 1906.

- The Reclamation Service became an independent agency in 1907, and the Survey's Chief Hydrographer, F.H. Newell, became its Director.

- Cooperating Federal agencies for Geological Survey waterresources investigations by 1907 were the Reclamation Service, the Forest Service, and the Indian Service.

- The Water-Utilization Division was created in 1910 to classify public lands for waterpower, irrigation, and reservoir sites.

- Systematic measurements of ground-water levels in Idaho began about 1912 and in Connecticut in 1913.

- Under international coordination with the Canadian Irrigation Office in 1913, six international gaging stations on the St. Mary River and the Milk River and its tributaries were being jointly maintained.

- In the Columbia River basin, two stations were operated jointly with Canada: the Pend Oreille River station (1915) and the Columbia River station (1916).

- In 1917, four more international gaging stations were jointly installed and operated on the St. Mary and Milk Rivers, and, in 1918, three additional stations were added, making a total of 13 international stations in operation on the St. Mary and Milk Rivers.

- The Water Resources Branch established its water quality laboratory for the study of mineral content of water in 1918.

- By 1919, the National Park Service and the Army Engineers were added to the growing list of Federal cooperators.

- The Water Resources Branch provided the necessary streamflow records and examined proposed projects on public lands outside the National Forests for the Federal Power Commission that was established in 1920 to issue licenses for the development of waterpower on Federal lands,

- Publications of the Geological Survey related to water resources had grown to more than 500 by 1925 .

\section{RAPID GROWTH, RAPID CHANGE: 1925-1960}

By 1925, although most of the work of the Water Resources Branch continued to be stream gaging, the demand for ground water for municipal or irrigation supplies had increased so that the issue of overdevelopment began to receive considerable attention.

- To meet new and stronger demands for information on the availability and efficient use of ground water, observation wells began to be measured in New Jersey by 1923 and in Pennsyvlania by 1925.

- In 1928, Congress formally recognized the Federal-State partnership and limited the federal financial contribution for cooperative water-resources studies to no more than 50 percent of the funds for each investigation.

- Streamflow was being measured at 2,238 gaging stations by 1929.

- In 1933, Survey data were used by the new Public Works Administration for projects involving water resouices.

- The Water Resources Branch began extensive studies in 1933 into the relationship of rainfall to runoff and of the magnitude and frequency of floods. 
- During the period 1927-1933, some 12 additional States were added to the network of ground-water observation wells for the systematic collection of water-level data, and, between 1934 and 1935, ten more States were added to the observation well network.

- The first official involvement of U.S. Federal Agencies in international programs began in 1938 when President Roosevelt created the Interdepartmental Committee on Scientific and Cultural Cooperation under direction of the Department of State, and, in 1944, the Water Resources Branch began special studies of the water resources of Saudi Arabia.

- By 1945, attention focused on water losses due to evaporation and on sedimentation problems in reservoirs, and studies into saltwater encroachment were underway in some coastal areas.

- The monthly Water Resources Review (now National Water Conditions) was established in 1945.

- The present-day title of "Water Resources Division" was established January 1, 1949, by Survey Order No. 173.

- The Foreign Hydrology Section (now Branch of International Hydrology) was established in 1952.

- In 1954, streamflow data were being collected at about 6,400 gaging stations and the chemical quality was being determined for more than 85,000 water samples.

- The ground-water observation well network had been extended nationwide by the end of 1960 .

- BY 1960, more than 1,700 water resources-related reports had been published.

\section{NEW GOALS, NEW EXPECTATIONS: 1960-1980's}

In September 1962, Congress extended the authority of the Survey to areas outside the national domain. In 1964, a long-range plan for the Geological Survey was prepared: The collection of basic water data would increase by about 50 percent in the decade 1964-1973; recording and processing of water data would be automated by 1968; generalized or detailed ground-water information for 75 percent of the country and reconnaissance information for the remainder would be available by the end of 1974; and research in the water-resources program would be increased 25 percent in the decade.

- In 1964, the Office of Water Data Coordination was formed within the Water Resources Division in response to Bureau of the Budget Circular A-67 establishing guidelines for coordinating Federal activities in developing a national plan for acquiring water data.

- By 1971, streamflow data were being collected at more than 11,000 gaging stations and water quality data at 4,000 stations.

- During the 1970 's, studies were being made to delineate hazards associated with mudflows, ground subsidence, and floods, and advances were made toward the ability to predict some of these disasters.

- In 1977, the Regional Aquifer-System Analysis (RASA) Program was established to study the Nation's ground-water systems on a regional scale.

- The National Water-Use Information Program, a Federal-State Cooperative Program designed to collect, store, and disseminate water-use information both nationally and locally, was begun in 1978 to meet the need for a single source of uniform information on water use.

- In the late 1970 's, the Department of Energy became a cooperator with the Survey through the Water Resources Division's ongoing nuclear-waste research program.

- In 1982, the Water Resources Division established an interdisciplinary program, the Hazardous Waste Hydrology Program, to provide the expertise in geology, geophysics, chemistry, and hydrology necessary to evaluate the common problems of nuclear and toxic-chemical waste disposal.

- The Geological Survey was selected in 1982 by the Interagency Task Force on Acid Precipitation as lead Federal agency in developing a National Trends Network of precipitation-collection sites to monitor the chemical composition of precipitation.

- Between 1975 and the end of 1982 alone, more than 8,000 new reports were added to the growing base of essential water-resources investigations.

- The National Water Summary Program, begun in 1982, keeps the Congress, Federal, State, and local agencies, and the general public informed about changes and trends in the availability, quantity, quality, and use of the Nation's water resources.

- In 1983, the Geological Survey assumed responsibility for the administration of the Water Resources Research Institutes and, in 1985, of the National Water Research Projects Grants Program.

- More than 13,000 continuous and part-time stream gaging stations and almost 36,000 ground-water observation wells provided data on the height, flow, and volume of water in the Nation's streams and aquifers in 1984, and the natural and man-induced quality of those water resources were being monitored at more than 12,000 stations. These water data have been transferred to computers that can be accessed through the Water Resource Division's WATSTORE data base.

By 1985, more than 900 cooperators were included in the Federal-State Cooperative Water Resources Program.

- During 1982-85, a state-of-the art network of minicomputers was installed in Water Resources Division offices nationwide to support research, hydrologic simulations, the national hydrologic data base, and management activities.

\section{NOW AND INTO THE FUTURE}

Other ongoing investigations encompass sedimentation, chemistry of and bacteria in water, quality of rainwater and snowmelt (acid precipitation), and movement and extent of glaciers; saltwater encroachment into fresh ground-water supplies near coastlines; flood frequency analysis and mapping of areas subject to flooding; information on the amount of water used, when it is used, and how it is used; and studies of the Nation's ground-water systems on a regional scale. The National Water Summary Program organizes water information annually for use by those who prepare water assessments and to increase public understanding of the nature, geographic distribution, magnitude, and trends of the Nation's water resources.

Major water-resources issues that are expected to continue into the 21st century will require continuing research by the $\mathrm{Na}$ tion's largest water-resources investigating agency into the availability and competition for water, degradation of water quality, and the management of water and land resources.

\section{BIBLIOGRAPHY}

Condes de la Torre, A., 1984, Water data program: U.S. Geological Survey Water Fact Sheet, $1 \mathrm{p}$.

Davis, A.P., 1897, Irrigation near Phoenix, Arizona: U.S. Geological Survey Water-Supply Paper 2, $98 \mathrm{p}$.

Rabbitt, M.C., 1980, Minerals, lands, and geology for the common defence and general welfare, volume 2, 1879-1904: U.S. Geological Survey, $407 \mathrm{p}$.

U.S.Geological Survey, 1936, Water levels and artesian pressure in observation wells in the United States in 1935: U.S. Geological Survey Water-Supply Paper 777, $268 \mathrm{p}$.

Wilson, H.M., 1896, Pumping water for irrigation: U.S. Geological Survey Water-Supply Paper 1,57 p.

For further information contact:
Chief Hydrologist
U.S. Geological Survey
409 National Center
Reston, Virginia 22092 